\title{
STRATEGI CALON ANGGOTA LEGISLATIF PEREMPUAN DALAM UPAYA MEMENANGKAN PEMILIHAN LEGISLATIF 2019 KOTA PADANGSIDIMPUAN
}

\author{
Elfi Syahri Ramadhona1), Natalia Parapat ${ }^{2)}$ \\ Universitas Muhammadiyah Tapanuli Selatan \\ elfichan408@gmail.com \\ natalia.parapat@um-tapsel.ac.id
}

\begin{abstract}
Abstrak
Menurut Undang-Undang Nomor 2 Tahun 2011 Tentang Partai Politik dan UndangUndang Nomor 7 Tahun 2017 tentang pemilihan umum anggota DPR, DPD, DPRD menggaris bawahi setiap partai politik peserta pemilu mengajukan anggota calon legislatif untuk setiap daerah pemilihan dengan memperhatikan partisipasi perempuan sekurangkurangnya $30 \%$ dengan kuota $30 \%$. Tetapi di Kota Padangsidimpuan bukan lagi pada proses pencalonan anggota legislatif perempuan, tetapi proses bagaimana agar caloncalon legislatif perempuan tersebut mampu memenuhi kuota minimal 30\% untuk mengisi kursi yang tersedia. Penelitian ini bertujuan untuk mengetahui strategi apa saja yang dilakukan oleh calon legislatif perempuan dalam upaya memenangkan pemilihan legislatif 2019 Kota Padangsidimpuan beserta kelemahannya. Metode penelitian yang digunakan adalah penelitian kualitatif dengan pendekatan analisis deskriptif. Teknik pengumpulan data melalui observasi, wawancara, dan dokumentasi. Hasil penelitian menunjukkan bahwa strategi yang dilakukan oleh caleg perempuan meliputi: promosi dengan cara pemanfaatan media massa dan media cetak, menunjukkan produk dengan cara berinteraksi secara langsung dengan masyarakat, memahami place dengan cara berpartisipasi secara langsung dalam kegiatan masyarakat, dan memberi harga dengan cara mengandalkan peran tim sukses dalam kampanye. Sedangkan kelemahan dari pelaksanaan strategi bahwa partai politik tidak memiliki cara khusus guna mengangkat keterwakilan perempuan di lembaga legislatif. Strategi politik seluruhnya diserahkan kepada caleg masing-masing. Bahkan ada beberapa partai politik dimana keberadaan perempuan sebagai caleg hanya sebatas untuk memenuhi syarat partai politik menjadi peserta pemilu. Sehingga strategi yang digunakan oleh caleg perempuan belum matang atau belum dilakukan secara mendalam hanya menyentuh dasar-dasar dari teori strategi itu saja.
\end{abstract}

Kata Kunci: Strategi, Caleg Perempuan, Pemilihan Legislatif

\begin{abstract}
Based on the Law Number 2 of 2011 concerning Political Parties and Law Number 7 of 2017 concerning the general election of members of the DPR, DPD, DPRD underlines every political party participating in the election submitting legislative candidate members for each constituency by taking into account the participation of women at least $30 \%$ with a $30 \%$ quota. But in Padangsidimpuan City, it is no longer the process of nominating female legislative members, but the process of how the women legislative candidates are able to fulfill a minimum quota of $30 \%$ to fill the available seats. This study aims to determine what strategies are carried out by women legislative candidates in an effort to win the 2019 legislative elections in Padangsidimpuan City along with their weaknesses. The research method used is qualitative research with a descriptive analysis approach. Data collection techniques through observation, interviews, and documentation. The results showed that the strategies carried out by female candidates included: promotion by using mass media and print media, showing products by interacting directly with the community, understanding places by participating directly in community activities, and giving prices by relying on the role successful team in the campaign. While the weakness of the implementation of the strategy is that political parties do not have a special way to raise women's representation in the legislature. The political strategy is entirely left to each
\end{abstract}


legislative candidate. There are even some political parties where the existence of women as legislative candidates is only limited to fulfilling the requirements of political parties to be participants in the election. So the strategies used by female candidates are immature or have not been done in depth only touching the basics of the theory of strategy alone.

Keywords: Strategy, Women Candidates, Legislative Elections

\section{PENDAHULUAN}

Undang-Undang Nomor 2 Tahun 2011 Tentang Partai Politik mengatur fungsi dan kewajiban partai politik dalam mewujudkan kesetaraan dan keadilan gender serta meningkatkan partisipasi dan peran perempuan dalam bidang politik, Sedangkan Undang-Undang Nomor 7 Tahun 2017 tentang pemilihan umum anggota DPR, DPD, DPRD menggaris bawahi setiap partai politik peserta pemilu mengajukan anggota calon legislatif untuk setiap daerah pemilihan dengan memperhatikan partisipasi perempuan sekurang-kurangnya $30 \%$ dengan kuota $30 \%$ perempuan diharapkan dapat mengambil posisi strategis di lembaga legislatif dan dapat mewarnai kebijakan negara.

Pemilihan legislatif 2019 di Kota Padangsidimpuan diikuti oleh 13 partai politik dimana partai politik yang berpartisipasi sudah menjalankan amanat Undang-Undang untuk mencalonkan anggota legislatif sekurang-kurangnya 30\% adalah perempuan. Dari 30 kursi DPRD yang akan diperebutkan, dengan minimal kuota $30 \%$, tentu caleg perempuan harus mampu mengisi minimal 9 kursi nantinya. Kelemahan yang terjadi di Kota Padangsidimpuan bukan lagi pada proses pencalonan anggota legislatif perempuan, tetapi proses bagaimana agar calon-calon legislatif perempuan tersebut mampu memenuhi kuota minimal $30 \%$ untuk mengisi kursi yang tersedia. Sebab, pada pemilihan legislatif tahun 2014 lalu, kursi DPRD Kota Padangsidimpuan hanya dimenangkan oleh 4 anggota legislatif perempuan saja. Hal ini terjadi, tentu disebabkan oleh strategi yang digunakan oleh caleg perempuan belum bisa meyakinkan pilihan masyarakat. Masyarakat cenderung meyakini bahwa politik itu identik dengan laki-laki bukan perempuan.
Secara umum, pemilih menjatuhkan pilihannya didasari oleh orientasi policy problem solving dan orientasi ideology (Firmanzah, 2008: 109). Orientasi policy problem solving adalah pemilih menaruh perhatiannya pada caleg perempuan yang mampu menawarkan solusi terbaik terhadap permasalahan masyarakatnya. Orientasi ideology menggambarkan bahwa masyarakat akan memilih caleg perempuan didasari oleh adanya ikatan ideologi. Pemilih ideologi lebih menekankan aspekaspek subjektifitas seperti kedekatan nilai, budaya, agama, moralitas, norma, emosi, dan psikografis. Untuk itu, caleg perempuan harus mampu mengelola sistem komunikasi dengan baik. Komunikasi tersebut berfungsi untuk menyampaikan ide perubahan kepada masyarakat dengan cara yang santun dan bijak. Pengetahuan akan budaya masyarakat dapat menjadi modal utama dalam pembentukan strategi politik. Begitu pula halnya dengan caleg perempuan di Kota Padangsidimpuan harus bisa menggunakan strategi yang lebih jitu dan bisa merubah pola pikir masyarakat. Sehingga caleg perempuan pada pemilihan legislatif 2019 bisa memenangkan minimal $30 \%$ dari kursi yang akan diperebutkan.

Dari pemaparan latar belakang di atas, maka penulis tertarik untuk melakukan penelitian dengan judul "Strategi Calon Legislatif Perempuan Dalam Upaya Memenangkan Pemilihan Legislatif 2019 Kota Padangsidimpuan."

\section{TINJAUAN PUSTAKA}

\section{Pengertian Strategi}

Kata strategi pada mulanya sangat akrab di kalangan militer, secara etimologis berasal dari kata majemuk bahasa Yunani, yaitu Strategos yang berarti pasukan dan agein yang berarti memimpin atau Strategia yang berarti kepemimpian atas pasukan, seni memimpin pasukan. (Schroder. 2009:1). Dalam Wikipedia Indonesia 
pengetian strategi adalah rencana jangka panjang dengan diikuti tindakan-tindakan yang ditujukan untuk mencapai tujuan tertentu, yang umumnya adalah "kemenangan".

Henry Mintzberg dalam Schroder Peter (2009:3) yang dikutip oleh Hendra Fauzi menyatakan bahwa studi strategi dan studi hubungan internasional merupakan hal yang sangat berkaitan. Keduanya dapat dibedakan secara substansial namun sulit untuk dipisahkan. Terwujudnya suatu strategi pada asasnya melalui empat tahapan :

1) Tahap perumusan yaitu, perbuatan intelektual

Tahap pertama diartikan sebagai keseluruhan keputusan-

keputusan

kondisional yang menetapkan tindakan-tindakan yang harus dijalankan guna menghadapi setiap keadaan yang mungkin terjadi di masa depan.

2) Tahap pemutusan yaitu, perbuatan politis

Tahap kedua yakni peralatan politik meliputi diplomasi, kebijakan (politik), pertahanan ekonomi, peralatan psikologi dan angkatan bersenjata. Peralatan ekonomi meliputi semua potensi ekonomi masyarakat.

3) Tahap pelaksanaan yaitu, perbuatan teknis

Pada tahap ketiga, pengertian strategi mengalami evolusi dari pengertian sempit ke pengertian luas. Dalam pengertian sempit, strategi diartikan sebagai seni menggunakan kekuatan militer untuk mencapai tujuan-tujuan yang telah ditetapkan oleh politik. Secara luas strategi diartikan sebagai seni menggunakan berbagai kekuatan yang dimiliki untuk mencapai tujuan-tujuan yang ditetapkan oleh politik

4) Tahap penilaian adalah perbuatan intelektual

Berdasarkan pengertian di atas dapat disimpulkan bahwa strategi adalah upaya menyusun perencanaan dengan langkah-langkah sistematis guna memenangkan suatu pertempuran secara politis. Terdapat unsur-unsur tambahan agar berbagai strategi yang telah disusun (direncanakan), berjalan maksimal yaitu, taktik. Taktik yang baik sangat diperlukan dalam memukul atau mengalahkan lawan, secara ideologi maupun politik.

\section{Strategi Politik}

Strategi politik adalah strategi yang digunakan untuk meralisasikan cita-cita politik. Strategi politik biasa digunakan dalam usaha merebut atau mempertahankan kekuasaan, terutama saat pemilihan umum. Strategi ini berkaitan dengan strategi kampanye, dengan tujuan untuk memperoleh kekuasaan dan pengaruh sebanyak mungkin dengan cara meraih hasil (suara) yang maksimal di pemilu, guna mendorong kebijakankebijakan yang dapat mengarah pada perubahan masyarakat (Schroder. 2009: 7).

Menurut Niffenegger dalam Firmanzah (2008: 199) yang dikutip oleh Hendra Fauzi mengatakan setidaknya terdapat empat strategi dalam marketing politik yang dapat digunakan oleh caleg perempuan yaitu, Produk, Promosi, Harga dan Place (tempat). Pertama, Produk. Dalam hal ini parpol atau caleg digambarkan sebagai "barang". Produk merupakan sesuatu yang ditawarkan kepada konsumen (pemilih). Produk dapat dirasakan keindahan, kenyamanan dan kenikmatannya ketika telah digunakan (dipilih). Kebermanfaatan keberadaan caleg perempuan dapat dirasakan ketika telah terpilih sebagai wakil mereka (rakyat) di parlemen. Untuk itu, mutu dari sebuah produk merupakan hal utama yang dapat menarik perhatian masyarakat. Produk politik dibagi dalam tiga (3) kategori yaitu, Party Platform (Platform Partai), Past Record (catatan masa lalu), Personal Characteristic (Ciri Pribadi).

Kedua, Promosi. Caleg perempuan harus mampu melakukan promosi secara maksimal. Promosi dapat dilakukan melalui media lisan maupun tulisan. Promosi akan terasa lebih maksimal ketika caleg perempuan mampu memperhatikan tingkat elektabilitas media promosi tersebut. Hal itu disebabkan karena tidak semua media tepat dijadikan sebagai alat promosi. Promosi dapat dibedakan atas tiga jenis 
yaitu, advertising, publikasi dan event debat.

Ketiga, Harga. Dalam politik, harga digolongkan ke dalam tiga hal yaitu, harga ekonomi, harga psikologis, dan harga image (citra) nasional. Harga ekonomi meliputi semua biaya yang dikeluarkan institusi politik selama periode kampanye. Harga psikologis yaitu mengacu kepada kenyamanan masyarakat atas latar belakang dari caleg perempuan seperti, etnis, agama dan pendidikan. Harga image nasional berkaitan dengan citra seorang caleg. Caleg perempuan harus dapat membentuk persepsi masyarakat bahwa dirinya mampu memberikan citra positif bagi daerah dan menjadi kebanggaan nasional.

Keempat, tempat (Place). Caleg perempuan harus memperhitungkan wilayah atau daerah yang menjadi basis suaranya. Dalam berkampanye caleg harus mampu mengidentifikasi, memetakan struktur dan karakteristik masyarakat di setiap daerahnya. Identifikasi dilakukan dengan melihat konsentrasi penduduk di setiap daerah, penyebarannya dan kondisi fisik geografisnya. Pengetahuan caleg terhadap berbagai hal tersebut memudahkan dalam menentukan dan merumuskan strategi yang pantas bagi masyarakat dengan keadaan geografis dan karakteristiknya masing-masing.

Kemampuan dan pemahaman caleg dalam mengkolaborasikan keempat rangkaian strategi marketing politik tersebut akan memudahkan masyarakat dalam menentukan pilihannya. Hal itu tentu akan berdampak signifikan bagi perolehan suara politik yang diraih oleh caleg perempuan. Keberhasilan strategi politik akan terbukti dalam pemilihan legislatif. Strategi yang baik dapat meningkatkan suara hingga hal yang tidak terbayangkan, menjadikan caleg perempuan sebagai orang nomor satu di daerahnya dan terpilith sebagai anggota legislatif. Kesalahan dalam penerapan strategi akan berdampak negatif bagi perolehan suara politik hingga hal yang tidak terbayangkan, bahkan dapat menghabiskan harta benda yang dimiliki.

\section{Calon Legislatif Perempuan}

Caleg Perempuan adalah para perempuan yang dipilih atau dipercaya oleh partai politik untuk menjadi peserta dalam pemilihan umum anggota legislatif pada periode tahun tertentu. Strategi politik caleg perempuan adalah suatu rangkaian asas/prinsip, keadaan, cara dan alat yang digunakan oleh perempuan untuk memenangkan pemilihan anggota legislatif di daerah tertentu.

\section{Pemilihan Legislatif}

Undang-Undang No 7 Tahun 2017 tentang Pemilihan Umum Anggota Dewan Perwakilan Rakyat, Dewan Perwakilan Daerah, dan Dewan Perwakilan Rakyat Daerah Pasal 1 menjelaskan bahwa Pemilihan Umum, selanjutnya disebut Pemilu, adalah sarana pelaksanaan kedaulatan rakyat yang dilaksanakan secara langsung, umum, bebas, rahasia, jujur, dan adil dalam Negara Kesatuan Republik Indonesia berdasarkan Pancasila dan Undang-Undang Dasar Negara Republik Indonesia Tahun 1945. Di saat itu, masyarakat dapat menyalurkan sikap politiknya dalam proses pemilihan wakilwakil rakyat.

\section{METODE}

\section{Jenis Penelitian}

Adapun jenis penelitian yang digunakan adalah metode penelitian kualitatif dengan pendekatan analisis deskriptif, dimana menurut Afrizal dalam Sugiyono (2009:54) metode penelitian kualitatif adalah suatu metode penelitian ilmu-ilmu sosial yang mengumpulkan dan menganalisis data berupa kata-kata (lisan maupun tulisan) dan perbuatan-perbuatan manusia.

\section{Informan Penelitian}

Di dalam penelitian kualitatif, istilah responden atau subjek penelitian disebut dengan istilah informan. Menurut Moloeng (2009:135) informan adalah orang yang memberi informasi tentang data yang diinginkan peneliti berkaitan dengan penelitian yang sedang dilaksanakannya.

Dalam menentukan informan digunakan teknik pengambilan sampel dengan cara purposive (disengaja). Adapun yang menjadi informan dalam penelitian ini adalah salah satu calon anggota legislatif perempuan dari setiap parpol yang maju pada pemilihan legislatif 2019 Kota Padangsidimpuan. 


\section{Tahapan Penelitian}

Penelitian ini menggunakan beberapa tahapan yang dilakukan dalam kurun waktu satu tahun diantaranya :

a. Tahap persiapan

Dalam tahapan ini adalah penyusunan proposal, pembuatan wawancara dan juga kelengkapan yang berhubungan dengan pengurusan izin penelitian, pada tahapan ini dilakukan sekitar dua bulan lamanya.

b. Tahap pelaksanaan

Pada tahapan ini peneliti terjun ke lokasi penelitian dengan melakukan pengumpulan data atau observasi (pengamatan), melakukan wawancara dan melakukan dokumentasi. Tahapan ini dilakukan sekitar lima bulan.

c. Tahap pengumpulan dan analisis data Setelah peneliti melakukan kegiatan dan kajian maka tahap selanjutnya adalah penyusunan laporan penelitian. Setelah disusun, maka disederhanakan dan dijelaskan sesuai dengan permasalahan penelitian agar mudah dibaca dan diinterpretasikan. Pada tahapan ini dilakukan selama dua bulan.

d. Tahap penyusunan laporan

Dalam tahapan penyusunan laporan, peneliti melakukan beberapa tahapan, mulai dari pembuatan laporan kemajuan, mengadakan atau mengikutsertakan dalam seminar hasil, dan melakukan penyempurnaan laporan akhir. Tahapan ini dilakukan dalam empat bulan.

e. Tahap publikasi ilmiah

Setelah laporan sudah tersusun dan dianggap final maka peneliti akan melakukan publikasi ilmiah baik melalui jurnal lokal maupun nasional. Tahapan ini dilakukan satu bulan lamanya.

f. Tahap pengiriman laporan

Dan tahapan terakhir adalah pengumpulan dan pengiriman hasil penelitian.

\section{Defenisi Konsep}

Adapun yang menjadi defenisi konsep pada penelitian ini adalah :

1. Strategi adalah strategi adalah upaya menyusun perencanaan dengan langkah-langkah sistematis guna memenangkan suatu pertempuran secara politis

2. Strategi politik yang bisa dilakukan oleh caleg perempuan adalah strategi dalam marketing politik yaitu, Produk, Promosi, Price (harga) dan Place (tempat)

3. Calon legislatif perempuan adalah para perempuan yang dipilih atau dipercaya oleh partai politik untuk menjadi peserta dalam pemilihan umum anggota legislatif pada periode tahun tertentu

4. Pemilihan legislatif adalah sarana pelaksanaan kedaulatan rakyat yang dilaksanakan secara langsung, umum, bebas, rahasia, jujur, dan adil dalam memilih wakil rakyat seperti DPR, DPD, dan DPRD.

\section{Teknik Pengumpulan Data}

Untuk membuat laporan akhir diperlukan teknik pengumpulan data yang baik. Teknik pengumpulan data mempunyai hubungan dengan masalah penelitian. Dalam penelitian ini teknik pengumpulan data yang digunakan adalah:

1. Observasi yaitu pengumpulan data dengan cara mengadakan pengamatan langsung ke lokasi penelitian

2. Wawancara mendalam, dilakukan berdasarkan instrumen pedoman wawancara yang ditujukan kepada informan penelitian.

3. Analisis Dokumen, dilakukan untuk mengumpulkan data yang bersumber dari dokumen yang ada hubungannya dengan penelitian tersebut

\section{Teknik Analisa Data}

Tahapan dalam analisis data dimulai dengan:

1. Reduksi data (Data Reduction) yaitu merangkum, memilih hal-hal yang pokok, dan memfokuskan pada halhal yang penting.

2. Penyajian data, melalui penyajian data tersebut, maka data terorganisasikan, tersusun dalam pola hubungan, sehingga akan semakin mudah dipahami.

3. Penarikan simpulan dan verifikasi. Kesimpulan dalam penelitian kualitatif merupakan temuan baru yang sebelumnya belum pernah ada. Temuan dapat berupa deskripsi atau gambaran suatu objek yang sebelumnya masih remang-remang atau gelap 
sehingga setelah ditelti menjadi jelas, dapat berupa hubungan kausal atau interaktif, hipotesa, dan teori.

\section{HASIL PENELITIAN}

Pemilihan legislatif 2019 lalu di Kota Padangsidimpuan menyisakan peta persaingan yang ketat diantara masingmasing caleg. Berbagai pendekatan kepada masyarakat telah dilakukan oleh masing-masing caleg guna mendulang suara sebanyak-banyaknya. Munculnya nama-nama baru dalam Daftar Calon Tetap menjadi tantangan tersendiri bagi incumbent. Incumbent yang ingin mencalonkan diri kembali harus dipusingkan dengan munculnya kekuatan- kekuatan baru yang diyakini telah mempersiapkan strategi jitu untuk merebut suara di dapil mereka. Begitu pula sebaliknya, pengalaman yang minim dalam memetakan wilayah menjadi salah satu kendala new comer dalam menjalankan strateginya. Ditambah lagi, tidak mudah merebut suara pemilih di suatu dapil yang telah dikondisikan oleh seorang incumbent. Untuk itu, hanya strategi kampanye yang paling jitu yang akan memenangkan persaingan. Dalam hal ini peneliti sengaja mengklasifikasikan 4 strategi marketing politik yang umumnya digunakan calon anggota legislatif perempuan terpilih di DPRD Kota Padangsidimpuan pada Pileg 2019. Diantaranya yaitu:

\section{A. Promosi Dengan Cara Pemanfaatan Media Massa dan Media Cetak \\ Promosi merupakan syarat utama dalam berpolitik. Promosi menjadi alat komunikasi efektif guna menyampaikan aspirasi dan tujuan pencalonan diri seorang caleg. Dengan demikian, proses penyampaian informasi dan hubungan interaksi antar kelompok dapat tersalurkan secara lebih efektif dan efisien. Promosi akan menggambarkan mekanisme pembentukan dan penerapan strategi politik caleg perempuan.}

Caleg perempuan harus mampu melakukan promosi secara maksimal.
Promosi dapat dilakukan melalui media lisan maupun tulisan. Promosi akan terasa lebih maksimal ketika caleg perempuan mampu memperhatikan tingkat elektabilitas media promosi tersebut. Hal itu disebabkan karena tidak semua media tepat dijadikan sebagai alat promosi. Promosi dapat dibedakan atas tiga jenis yaitu, advertising, publikasi dan event debat.

Keterkaitan media massa maupun media cetak dengan politik disinyalir memberikan pengaruh terutama dalam pembentukan citra politikus. Melalui media massa dan media cetak akan diinformasikan berita-berita yang positif berupa prilaku baik dari politikus yang turut dalam kegiatan sosial dan peduli lingkungan sehingga akan membentuk pendapat umum tertentu bagi yang mereka menyaksikannya. Oleh sebab itu, pemanfaatan media massa secara maksimal akan dibutuhkan dalam menarik hati pemilih untuk memilih calon legislatif perempuan.

Informan A (caleg PKB) yang berada di dapil 2 misalnya, dalam menjalankan strategi kampanyenya, beliau menggunakan atribut kampanye berupa baliho, banner dan spanduk bergambarkan dirinya beserta partai politik pengusung (PKB). Selain itu, beliau juga membuat kartu nama untuk mempermudah masyarakat mengingatnya sebagai calon legislatif. Bukan hanya Informan A saja, tetapi semua caleg perempuan yang peneliti jumpai juga menggunakan strategi ini. Perlengkapan tersebut digunakan untuk menarik simpati masyarakat desa agar memilihnya. Tindakan tersebut juga dilakukan sebagai upaya mempertahankan suara politiknya sehingga tetap stabil.

B. Menunjukkan Produk Dengan Cara Berinteraksi Secara Langsung dengan Masyarakat

Produk dalam partai politik sangat terkait dengan sistem nilai, di dalamnya melekat janji dan harapan akan masa depan, dan penyampaian visi yang bersifat aktraktif. Interakasi ini 
dilakukan dengan melakukan orasi secara langsung dan terbuka yang berisi himbauan, ajakan, bahkan doktrin. Tujuannya utamanya adalah untuk menarik massa dan mengumpulkan suara sebanyak mungkin. Selain menyampaikan visi misinya, seorang kandidat politik biasanya juga sering memanfaatkan kondisi tersebut untuk menebar isu-isu dan janji-janji kepada masyarakat. Berinteraksi secara langsung dengan masyarakat merupakan suatu strategi yang dapat digunakan caleg untuk menarik simpati masyarakat.

Dalam proses ini masyarakat akan dapat menilai bagaimana kualitas caleg yang akan terlihat dari isu yang dibawanya serta bagaimana cara caleg merespon segala pertanyaan dan permintaan masyarakat di dapilnya. Kesan awal yang baik akan sangat membantu caleg untuk dapat melakukan pendekatan lebih intens kepada masyarakat. Proses berinteraksi langsung dengan masyarakat sangat identik dengan isuisu politik yang dibawa oleh caleg Informan B (Caleg Partai Demokrat) yang berada di dapil 2 dan merupakan incumbent juga misalnya, dalam menjalankan strategi kampanyenya, beliau terlebih dahulu memahami bagaimana kondisi nyata yang terjadi di dapilnya. Seperti yang terjadi di daerah pemilihan Padangsidimpuan Angkola Julu (dapil 2) dimana mayoritas masyarakatnya berprofesi sebagai petani salak. Selama ini, petani hanya menjual hasil panennya dalam bentuk buah salak. Kemudian beliau memberikan ide, jika buah salak ini bisa diolah menjadi produk lain yang tentu saja akan menghasilkan rupiah yang lebih menjanjikan lagi. Beliau berencana akan memberdayakan petani-petani salak tersebut supaya bisa menciptakan UKM dengan bahan baku buah salak menjadi aneka olahan yang hasilnya tentu lebih menjanjikan bagi masyarakat petani salak.

Sementara itu, Informan C (Caleg Partai Gerindra) yang berada di dapil
3 , beliau menyampaikan tujuannya jika terpilih nanti adalah terbentuknya pemerataan pembangunan di Padangsidimpuan Selatan.

C. Memahami Place Dengan Cara Berpartisipasi Secara Langsung Dalam Kegiatan Masyarakat

Caleg perempuan harus

memperhitungkan wilayah atau daerah yang menjadi basis suaranya. Dalam berkampanye caleg harus mampu mengidentifikasi, memetakan struktur dan karakteristik masyarakat di setiap daerahnya. Identifikasi dilakukan dengan melihat konsentrasi penduduk di setiap daerah, penyebarannya dan kondisi fisik geografisnya. Pengetahuan caleg terhadap berbagai hal tersebut memudahkan dalam menentukan dan merumuskan strategi yang pantas bagi masyarakat dengan keadaan geografis dan karakteristiknya masing-masing.

Berpartisipasi disini bertujuan untuk mengubah prilaku khalayak secara konkret dan terukur. Disini kandidat politik menunjukkan simpati dan kepeduliannya kepada masyarakat. Yaitu dengan cara melakukan kegiatan yang berhubungan dengan kehidupan masyarakat seperti melakukan bakti sosial dan pengadaan fasilitas umum dalam masyarakat. Meskipun kedengarannya menjanjikan perolehan suara yang banyak karena berpeluang besar menarik hati masyarakat melalui partisipasi caleg dalam berbagai kegiatan, nyatanya tidak semua anggota perempuan di DPRD Kota Padangsidimpuan menggunakan strategi ini ketika kampanye Pileg 2019 lalu. Masing-masing dari mereka memiliki pandangan yang berbedabeda dalam melakukan pendekatan ke masyarakat. Ada yang menyatakan tidak harus mengikuti secara langsung kegiatan masyarakat (dalam artian cukup menjadi donatur acara) atau setidaknya dapat menyumbangkan pikiran seperti saran atau solusi.

Informan D (Caleg Golkar) yang menjadikan semua golongan masyarakat baik golongan bapak- 
bapak, ibu-ibu maupun remaja sebagai objek kampanyenya menyatakan bahwa dalam kampanyenya tidak harus terlibat dengan kegiatankegiatan masyarakat. Terdapat kesamaan pendapat antara Informan D dan Informan E (Caleg PPP) dalam menjalankan strategi ini. Menurut mereka, dengan memberikan bantuan baik materi maupun non materi dalam berbagai kegiatan, sedikit banyaknya masyarakat akan mulai mencari tahu dan mengenal sosok mereka, masyarakat akan merasa senang ketika diperhatikan dan diayomi. Bantuan materi maupun non materi merupakan salah satu bentuk kepedulian caleg terhadap konstituennya yang tujuannya tidak lain adalah untuk meningkatkan ikatan emosional diantara mereka.

Pendapat berbeda kemudian juga diutarakan oleh calon anggota legislatif perempuan lainnya yang merupakan incumbent yaitu Informan F (Caleg PDIP) mengenai strategi berpartisipasi langsung dalam kehidupan masyarakat ini. Menurut Informan $F$ cara menunjukkan suatu kepedulian kepada masyarakat adalah dengan terlibat langsung dan mengikuti kegiatankegiatan masyarakat. Misalnya dengan mengikuti pengajian-pengajian di daerah tersebut atau turut serta hadir dalam acara musrenbangdes sekaligus menjanjikan suatu masukan berupa program yang akan beliau perjuangkan ketika diberikan amanah nantinya.

\section{Memberi Harga Dengan Cara Mengandalkan Peran Tim Sukses Dalam Kampanye}

Harga marketing politik digolongkan tiga hal yaitu, harga ekonomi, harga psikologis, dan harga image (citra) nasional. Harga ekonomi meliputi semua biaya yang dikeluarkan institusi politik selama periode kampanye. Harga psikologis yaitu mengacu kepada kenyamanan masyarakat atas latar belakang dari caleg perempuan seperti, etnis, agama dan pendidikan. Harga image nasional yaitu berkaitan dengan citra seorang caleg. Caleg harus dapat membentuk persepsi masyarakat bahwa dirinya mampu memberikan citra positif bagi daerah.

Salah satu strategi kampanye yang umumnya digunakan seorang caleg dalam pemilu adalah dengan mengandalkan peran tim sukses. Dalam hal ini tim sukses yang dimaksud yaitu dengan membentuk suatu tim yang bertugas terjun dalam masyarakat dan sebagai wakil dalam masyarakat. Tim ini berfungsi untuk mensosialisasikan terkait hal-hal apa saja yang telah dilakukan oleh kandidat politik khususnya berkenaan dengan pencalonannya dalam Pemilu. Biasanya untuk membentuk tim seperti ini, kandidat politik sangat mengandalkan peran tokoh masyarakat atau elit masyarakat agar dapat mengkondisikan pendukungnya terhadapnya.

Berdasarkan hasil wawancara yang dilakukan dengan semua informan mengenai keterlibatan tim sukses dalam upaya keterpilihannya, mereka mengatakan tanpa bantuan tim sukses akan sulit bagi mereka untuk mempromosikan diri mereka kepada masyarakat. Selain karena tidak mengetahui secara pasti aspirasi di suatu daerah, mereka juga umumnya sangat membutuhkan tokoh yang bisa mengajak banyak orang untuk beramai-ramai memilihnya. tidak sembarangan orang dapat dijadikan ketua tim sukses sekalipun orang tersebut menawarkan diri. Hal ini dikarenakan posisi tersebut merupakan posisi ujung tombak di lapangan, sehingga hanya orangorang kepercayaan yang dianggap mampu untuk menjalankan amanah yang telah diberikan.

Secara logika, ditengah zaman modern yang segala sesuatunya dinilai dengan uang, agaknya hampir mustahil seseorang bersedia bekerja siang dan malam secara suka rela demi menyukseskan seorang caleg agar terpilih dalam pemilu. Konsep yang ideal terkait hal ini seharusnya adalah terjadi suatu hubungan timbal balik yang saling menguntungkan 
antara tim sukses dan caleg terpilih. Dalam artian, ketika seorang caleg telah berhasil melenggang ke parlemen atas bantuan tim sukses, setidaknya ada suatu penghargaan dan feedback yang dapat diberikan caleg terpilih atas jerih payah tim sukses selama kampanye.

Menurut Informan F (Caleg PDIP), balas jasa yang sepadan diberikan kepada mereka yang telah rela berkorban menyukseskan keterpilihannya adalah memperjuangkan aspirasi konstituen melalui program-program yang pro kepada masyarakat. Sementara itu, pendapat yang berbeda kemudian disampaikan oleh Informan D (Caleg Partai Golkar) terkait timbal balik (feedback) yang diberikannya kepada tim suksesnya. Tidak saja memperjuangkan aspirasi konstituen melalui program-program yang pro kepada masyarakat, tetapi akan memberikan balas jasa kepada konstituennya melalui pemberian berbagai bantuan berupa materi. Selain sebagai salah satu bentuk balas jasa, pemberian bantuan berupa materi tersebut juga dianggap sebagai bentuk perhatian anggota legislatif terpilih kepada tim suksesnya agar tetap dapat menjaga hubungan silaturahmi sehingga akan saling bersinergi untuk kedepannya.

\section{KESIMPULAN DAN SARAN Kesimpulan}

Berdasarkan hasil penelitian yang diperoleh dapat disimpulkan ada 4 strategi yang dilakukan oleh caleg perempuan dalam upaya memenangkan pemilihan legislatif, yaitu:

1. Mempromosikan diri dengan memanfaatkan media massa dan media cetak

2. Menunjukkan produk dengan cara berinteraksi secara langsung dengan masyarakat

3. Memahami place dengan cara berpartisipasi secara langsung dalam kegiatan masyarakat

4. Memberi harga dengan cara mengandalkan peran tim sukses dalam kampanye

Dan kelemahan dari pelaksanaan strategi-strategi yang dilakukan adalah partai politik tidak memiliki cara khusus guna mengangkat keterwakilan perempuan di lembaga legislatif. Strategi politik seluruhnya diserahkan kepada caleg masing-masing. Bahkan ada beberapa partai politik dimana keberadaan perempuan sebagai caleg hanya sebatas untuk memenuhi syarat partai politik menjadi peserta pemilu. Sehingga strategi yang digunakan oleh caleg perempuan belum matang atau belum dilakukan secara mendalam hanya menyentuh dasar-dasar dari teori strategi itu saja. Hal ini terlihat dari hasil pemilihan legislatif di Kota Padangsidimpuan tahun 2019 yang baru saja selesai, kursi DPRD hanya dimenangkan oleh 6 caleg perempuan yang berhasil menduduki kursi DPRD. Yang artinya masih belum bisa memenuhi kuota $30 \%$.

\section{Saran}

Adapun saran-saran yang diberikan terhadap hasil penelitian ini adalah :

1. Partai politik harus lebih mempertimbangkan atau mempersiapkan strategi untuk membantu caleg perempuan dalam partainya bisa bersaing secara seimbang dengan caleg laki-laki, Caleg Perempuan jangan hanya dijadikan formalitas saja, dan

2. Caleg perempuan harus mempersiapkan strategi yang lebih jitu yang bisa menarik perhatian masyarakat.

\section{DAFTAR PUSTAKA}

Fauzi, Hendra. 2010. Strategi Politik Calon Legislatif Perempuan Dalam

Memenangkan Pemilihan Legislatif 2009. Fisip Universitas Lampung.

Firmanzah. 2008. Mengelola Partai Politik. Jakarta: Yayasan Obor Indonesia.

2007. Marketing Politik: Antara

Pemahaman dan Realita, Jakarta: Yayasan Obor Indonesia.

Lovenduski, Joni. 2005. Politik Berparas 
JURNAL ILMIAH MUQODDIMAH:

Jurnal IImu Sosial, Politikk Dan Humaniora

Perempuan. Yogyakarta: Kanisius.

Moloeng, Lexy. 2005. Metode Penelitian Kualitatif. Bandung: PT. Remaja Rosdakarya.

Sagala, Ofriendly, dkk. 2015. Strategi Kampanye Calon Legislatif Perempuan Menjelang Pemilihan Legilatif 2014 Di Kota Semarang, dalam Jurnal IImu Pemerintahan Fisip Universitas Diponegoro Semarang.

Schroder, Peter. 2009. Strategi Politik. Jakarta: Friedrich-Naumann-Stiftung fur die Freiheit, Indonesia.

Sugiyono. 2009. Metode Penelitian Kuantitatif, Kualitatif dan R\&D. Bandung: Alfabeta.

Undang-Undang Nomor 2 Tahun 2011 Tentang Partai Politik.

Undang-Undang Nomor 7 Tahun 2017 Tentang Pemilihan Umum. 